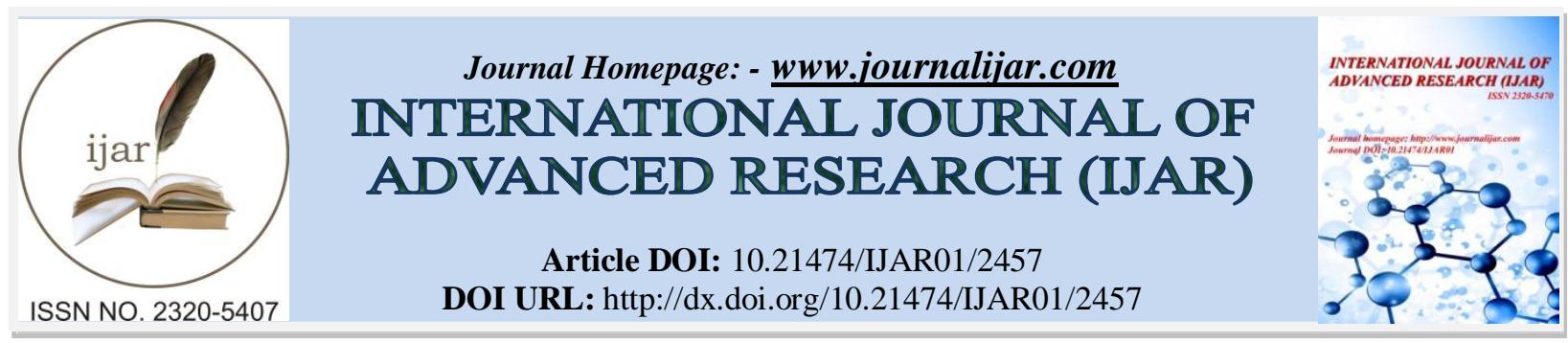

RESEARCH ARTICLE

\title{
PHYSICOCHEMICAL AND BACTERIOLOGICAL PROPERTIES OF SOME ALGERIAN TRADITIONAL DAIRY PRODUCTS 'KLILA AND JBEN' MARKETED IN SOUTHWEST OF ALGERIA AND THEIR IMPACT ON CONSUMERS HEALTH.
}

Elhassan Benyagoub ${ }^{1,3^{*}}$, Bettache Guessas ${ }^{1}$, Mohammed Ayat ${ }^{2}$ \& Brahim Sanebaoui $^{3}$.

1. Faculty of natural and life sciences, Department of Biology, Ahmed Ben bella University of Oran 1 (31000), Oran, Algeria.

2. Quality control laboratory, Oran (31000), Oran, Algeria.

3. Faculty of natural and life sciences, Department of Biology, Tahri Mohammed University of Bechar (08000), Bechar-Algeria.

\section{Manuscript Info}

Manuscript History

Received: 23 October 2016

Final Accepted: 21 November 2016

Published: December 2016

Key words:-

Food-borne infection,

Food safety, Jben, Klila,

Quality, Southwest of Algeria.
Abstract

The objective of this study is to identify the physicochemical and bacteriological characteristics of Algerian traditional cheeses namely Klila and Jben collected from southwestern of Algeria and their impact on public health.

The physicochemical and microbiological analyses of the samples allowed having an overview of the quality of these traditional dairy products. The macroscopic and microscopic examinations and biochemical testing of isolates helped to identify pathogenic strains namely Salmonella sp, Shigella sp and Staphylococcus aureus.

The results showed that the $\mathrm{pH}$ of the samples was acid corresponding to high levels of lactic acid with a high rate of dry matter content for 'Klila' which has allow humidity level. The bacteriological results showed a significant fecal contaminants rate namely fecal coliforms, with average values of $3,89 \times 10^{5}$ and $1,4 \times 10^{4} \mathrm{cfu} / \mathrm{g}$ for Klila and Jben products respectively. The telluric contamination was also found with an estimated rate of 96 and $40 \%$ for Klila and Jben respectively. However, no sample has been contaminated by Salmonella $s p$ or Shigella sp., but only one sample of Jben was contaminated by $S$. aureus with a charge of $0,3 \times 10^{3} \mathrm{cfu} / \mathrm{g}$, which may constitute a risk to consumer health.

Copy Right, IJAR, 2016,. All rights reserved.

\section{Introduction:-}

Several varieties of cheese are known and produced all over the world. The cheese has been made for centuries with traditional procedures by the natives. Then the manufacturing technology was transferred in the time that people traveled from one country to another. Currently the cheese is processed by modern technology based on the use of ferments under defined conditions to offer the product more microbiological safety and more sensory quality.

Algeria is a country where fermented dairy products are consumed traditionally, they were until recently made in rural areas, mainly for consumption by spontaneous fermentation of raw milk produced locally (El Marrachi and Hmmama, 1996). 
However, the Algerian traditional cheese varieties have not been studied thoroughly and are always confined at the family level. Some of these varieties have a good quality and have attractive properties in terms of flavor and texture. Therefore it's important to have knowledge on changing microbiological and biochemical properties during manufacture, as well as the parameters of their processes to produce a cheese with higher hygienic and technological quality.

Practically, few studies focused on Algerian cheeses in general and in particular Klila and Jben products, and there is not much data on their biochemical and microbiological characteristics and their transformation techniques.

This study aims to characterize the physicochemical and bacteriological properties of the traditional cheeses Klila and Jben, and their impact on public health in southwest of Algeria.

\section{Manufacturing process of traditional cheeses:-}

In Algeria, Klila and Jben are the most popular traditional cheeses and their traditional manufacturing methods are still in use until today (Hamama, 1989a). Nevertheless, there is an increased demand of this type of cheese, due to its pleasant taste and nutritional properties.

Although similar cheeses to Klila and Jben all over the world such as Jameed in Middle East and the Chhana in India are well characterized and produced on an industrial scale in continuous processes using new procedures such as atomization and lyophilization (Shaker et al.,1999; Dharam and Narender, 2007; Mazahreh et al., 2008; AL omari et al., 2008).

On the one hand, the Klila is a fermented cheese produced empirically in several regions of Algeria. It is manufactured by a relatively moderate heating $\left(55-75^{\circ} \mathrm{C}\right)$ from Lben until the latter is curdled $(10-15 \mathrm{~min})$, the curd is drained spontaneously or pressed by a stone, the resulting cheese is consumed as fresh or after drying. Klila is used as an ingredient after rehydration in traditional cooking. On the other hand, the Jben is a fresh cheese known and popular on the Algerian territory. It is produced by coagulation of fresh milk, then draining and molding the curd, and therefore the resulting cheese is ready for consumption.

In Europe, cheese valorization, like all traditional products, took place through various stages, whose main were to improve the production technology and to identify the factors affecting quality, as well as regulations for the protection and enhancement (eg: Protected appellation of origin, Protected geographical indication, guaranteed traditional specialty, etc.), that tend to preserve their peculiarities.

Even for Algerians dairy products, we headed towards the idea that we need to know what factors characterize them, in order to improve production technology and eliminate the hygienic risks (Galina et al., 2011). Therefore, a research should be made to keep the traditional skills, but at the same time, using modern knowledge; to have the right balance between quality, safety and convenience.

\section{Materials and methods:-}

\section{Samples:-}

The levies were performed at markets of Bechar City, Ain Sefra and Beni Abbes between the period from February and April 2016, with a total of thirty samples divided between 25 samples of Klila and 05 samples of Jben. The samples were placed in a cooler and transported directly to the laboratory for analysis, where they are held at pedagogical laboratory of Bechar University, whose purpose is to assess the hygienic quality of traditional dairy products marketed in southwest of Algeria.

\section{Physicochemical Analysis:-}

The studied physicochemical parameters were: $\mathrm{pH}$, titratable acidity $(\mathrm{g} / \mathrm{l})$, total solid content $(\%)$ and relative humidity $(\%)$.

The $\mathrm{pH}$ was determined by $\mathrm{pH}$ meter Starter 2C Lab, Shanghai China. The titratable acidity was determined by measurement of lactic acid with sodium hydroxide in the presence of phenolphthalein at $1 \%$ as a color indicator according to (NF V04-206, 1994; ISO 11869, 1997). 
Total solid content and water content were determined after drying in an oven at $103^{\circ} \mathrm{C} \pm 2$ (Drying method) according to (NF V04-207, 1994; ISO 13580, 2005).

The statistical treatment consisted of determining the average and standard deviation.

\section{Microbiological Analysis:-}

Sampling was performed in concordance with the Algerian standardized sampling methods (ISO 707, 1994). Microbiological analysis included after preparing decimal dilutions according to (ISO 8261, 2001), where the stock solution was prepared after homogenization using a Stomacher 400C LabBlenders, the detection and enumeration of bacteria indicators of fecal contamination or sanitary quality defects, and the search for suspected pathogenic bacteria, including;

Enumeration of total aerobic mesophilic flora incubated at $30^{\circ} \mathrm{C}$ for 72 hours according to (NF V 04-016, 1985) on Plate Count Agar (PCA) (Fluka, Spain); Detection and enumeration of total and fecal coliform incubated at 37 and $44^{\circ} \mathrm{C}$ respectively for 24 to 48hours according to (ISO 4832, 1978) on the middle Violet Red Bile Lactose Agar (VRBL) (Biochem, Canada). All red colonies (lactose + ) with a minimum diameter of 0,5mm appeared in 24hours are regarded as coliforms; Detection and enumeration of Staphylococcus aureus according to (ISO 5944, 2001)on the middle of Giolitti Cantoni (Institut Pasteur, Algeria) and Baird Parker agar (Fluka, Switzerland); Enumeration of sulphite-reducing clostridia spores at $46^{\circ} \mathrm{C}$ according to (NF T 90-415, 1985) by incorporation Meat liver agar (Fluka, India) in the deep tube, and finally Detection of Salmonella spp according to (ISO 6785, 2001) after preenrichment in non-selective liquid medium and enrichment in selective media (Rappaport-Vassiliadis and selenite/cystine middle) in a deep tube; afterward, isolation on selective media, Hecktoen agar (Diagnostici Liofilchem, Italy) and SS agar (Fluka, India).

Presumptive pathogenic strains isolated from selective media; Baird Parker, SS and Hecktoen have been tested to be identify by several biochemical tests 'Gram stain, catalase test, coagulase test, tests of classic gallery and miniaturized API 20E'.

Enumeration of Petri dishes having microorganisms is based on the standard set by legislation (AFNOR, 1980).

\section{Interpretation of Results:-}

The criteria for microbiological quality employed were in accordance with the publication on dairy products, Algerian standard (NA 35, 1998) and the Moroccan standard (NM 624-04, 2004), which is based on a 3-class plan following the specifications; $\mathrm{n}, \mathrm{c}, \mathrm{m}$ and $\mathrm{M}$.

The interpretation of the standards is based on the analysis of five units component the sample $(n=5)$ and measure the frequency of values between $\mathrm{m}$ to $\mathrm{M}$ range. Values at $\mathrm{m}$ above $\mathrm{M}$ in any sample are unacceptable relative to either health hazard, sanitary indicators a spoilage potential.

\section{Hazard analysis 'HACCP system':-}

The implementation of HACCP system "Hazard analysis and critical control points" system is performed in several successive stages, at first, it is to apply the prerequisite programs "PRP", hazards identification at each stage of production, processing or preparation of the product, evaluate the corresponding risks and to determine the stage where it is possible to act effectively (Faye and Loiseau, 2000).

The quality management by the analysis of risks or potential hazards associated with a product or process (HACCP) must be applied to the entire chain from the cow to the consumer (Leyral and Vierling, 2007). Hazard identification was performed using the Ishikawa diagram 'Diagram cause-effect' detailing 5 causes to consider "5M Method" (Medium, Workforce, materials, methods and equipment) to maintain a hygienic environment throughout the production (Notermans et al., 1994; Blanc, 2007), whereas the risk by approaching Zurich Hazard Analysis which involves assessing qualitatively and semi-quantitatively risk assessment, severity and frequency (Codex Alimentarius, 2003).

At each of the identified potential risks corresponding corrective actions pertinent and control plans, associated with critical limits, monitoring procedures and recording. 


\section{Results:-}

Physicochemical analysis:-

The average results of physicochemical parameters of Klila and Jben samples namely pH, titratable acidity, dry matter and relative humidity are represented in the table below (Table 1).

Table 1:- Physicochemical characterization of Klila and Jben samples.

\begin{tabular}{|c|c|c|c|c|}
\hline \multirow{2}{*}{ Parameters } & \multicolumn{4}{|c|}{ Mean values \pm standard deviation } \\
\cline { 2 - 5 } Products & $\mathrm{pH}$ & $\begin{array}{c}\text { Titratableacidity } \\
(\mathrm{g} / \mathrm{l})\end{array}$ & $\mathrm{DM}(\%)$ & $\mathrm{RH}(\%)$ \\
\hline Klila(25 Ech K) & $4,35 \pm 0,63$ & $10,1 \pm 4,41$ & $95,16 \pm 1,93$ & $4,84 \pm 1,93$ \\
\hline Jben $(5$ Ech J) & $5,51 \pm 0,21$ & $3,3 \pm 0,76$ & $56,12 \pm 21,28$ & $43,88 \pm 21,28$ \\
\hline
\end{tabular}

DM: Dry matter content, RH: Relative humidity, J; Jben, K: Klila, Ech; Samples, pH: potential of hydrogen.

The $\mathrm{pH}$ values measured indicate that the samples have acidic $\mathrm{pH}$ which means obtained are 4,35 and 5,51, with values ranging from 3,36 to 5,85 and 5,25 to 5,85 for Klila and Jben respectively.

However the average values found in titratable acidity of the samples analyzed are 3,3 and $10,1 \mathrm{~g} / \mathrm{l}$ with values range from 5 to 20,3 and from 2,6 to 4,6 g/l for Klila and Jben respectively.

The average levels of total dry matter of the samples analyzed were high, whose value obtained is $95,16 \%$, with variations going from 89,4 to $97,8 \%$ for Klila, whereas samples of Jben recognized an average of $56,18 \%$ with minimum values of 25,6 ; and $85,2 \%$ as maximum values.

However the average value of humidity is equal to 43,88 and $4,84 \%$, whose values found ranging from 2,2 to $10,6 \%$ and 14,8 to $74,7 \%$ for Klila and Jben respectively.

\section{Microbiological analysis:-}

The average results of bacteriological parameters of Klila and Jben are presented in the table below (Tab. 2).

Table 2:- Bacteriological characterization of Klila and Jben samples.

\begin{tabular}{|c|c|c|c|c|c|c|c|}
\hline \multirow{3}{*}{$\begin{array}{l}\text { Parameters } \\
\text { Products }\end{array}$} & \multicolumn{7}{|c|}{ Mean values } \\
\hline & \multirow{2}{*}{$\begin{array}{c}\text { GA } \\
\text { (cfu/g) }\end{array}$} & \multicolumn{2}{|c|}{ Coliforms (cfu/g) } & \multirow{2}{*}{$\begin{array}{c}\text { CSR } \\
(\mathrm{Spr} / 20 \mathrm{ml})\end{array}$} & \multicolumn{2}{|c|}{ Staph } & \multirow[t]{2}{*}{ Sal. } \\
\hline & & TC & FC & & SCN & S. aureus & \\
\hline Klila & $5,1 \times 10^{7}$ & $3,7 \times 10^{5}$ & $1,8 \times 10^{5}$ & 14,76 & $2,2 \times 10^{4}$ & $<1$ & Abs \\
\hline Jben & $2,88 \times 10^{6}$ & $1,4 \times 10^{4}$ & $<1$ & $<1$ & $7 \times 10^{2}$ & $0,3 \times 10^{3}$ & Abs \\
\hline
\end{tabular}

GT: total aerobic mesophilic flora, TC: total coliform, FC: fecal coliform, CSR: sulphite-reducing clostridia, SCN: coagulase-negative Staphylococci, S. aureus: Staphylococcus aureus, Sal. Salmonella sp, cfu: colony forming unit, g: gram, ml: milliliter, Spr: Spore, Abs: Absence.

Enumeration of total aerobic mesophilic flora revealed an average estimated $5,1 \times 10^{7}$ and $2,88 \times 10^{6} \mathrm{cfu} / \mathrm{g}$ for samples of Klila and Jben. These results indicate that these products of lactic fermentation were too loaded with aerobic germs (Fig.1).

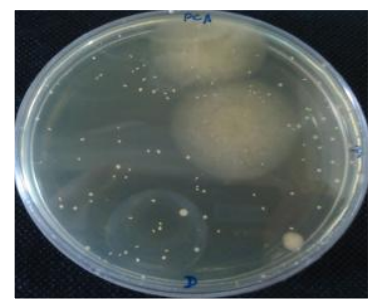

(a)

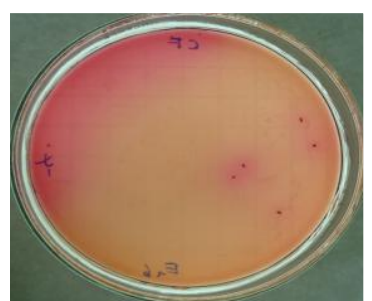

(b)

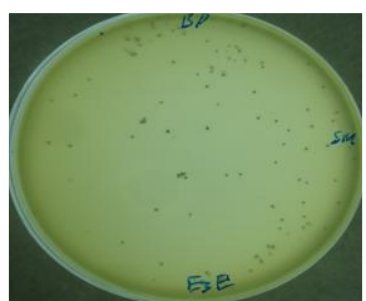

(c)

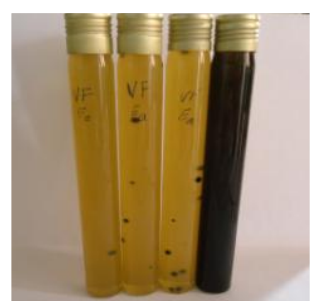

(d) 


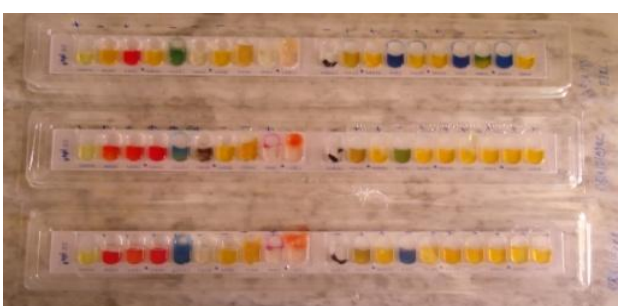

(e)

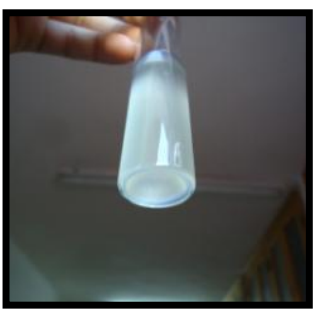

(f)

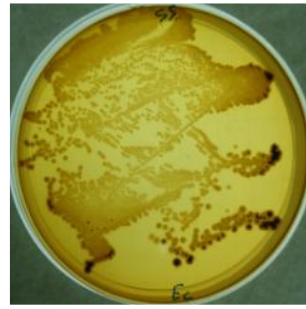

(g)

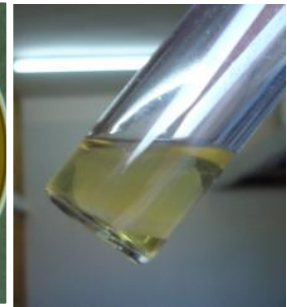

(h)

Figure 1:- Isolated strains of Klila and Jben samples (Original, 2015).

(a): Aerobic bacteria (PCA agar), (b): Total and fecal coliforms (VRBL agar), (c): Staphylococci (Baird Parker agar), (d): Sulphite-reducing clostridia (Meat Liver middle) (e): Miniaturized gallery API 20E, (f) Fecal streptococci (middle of Litsky Eva), (g): Suspected strains as Salmonella sp (SS agar), (h): Coagulase test.

Enumeration results of total coliforms show that the levels of these contaminants was important that the analyzed samples contained means of $3,89 \times 10^{5}$ and $1,4 \times 10^{4} \mathrm{ufc} / \mathrm{g}$ for the product of Klila and Jben respectively.

However, we reported the complete absence of these germs for eight samples namely k11, k12, k13, k19, k20 for Klila and $\mathrm{J} 2, \mathrm{~J} 3$, J5 for Jben.

While, fecal coliforms were present with an average value of $1,81 \times 10^{5} \mathrm{ufc} / \mathrm{g}$ for Klila samples. However, samples of Klila k6, k7, k10, k11, k12, k13, k19, k20, k21, and all samples of Jben appear free of these contaminating microorganisms.

Among the thirty samples of Klila and Jben analyzed, we have revealed the presence of coagulase-negative Staphylococci 'S. saprophyticus' in nine samples namely k1, k2, k5, k12, k13, k15, J1, J3 and J4. As well as we isolated coagulase positive Staphylococci "S. aureus" from one sample of Jben J5.

After identification of isolates suspected as Salmonella $s p$ or Shigella $s p$, the analyzed samples appear free from Salmonella $s p$ and Shigella $s p$ for different samples of Klila and Jben, while the isolated strains were identified as Enterobacter sakazakii, Escherichia coli and Serratia odorifera.

The sulphite-reducing clostridia spores were detected in Klila and Jben samples except the samples k15, J1, J4 and J5.

\section{Hazard analysis 'HACCP system ':-}

Table 3 provides an illustration of a commodity chain approach to hazard identification, for industrial and semiindustrial soft and pressed cheese subsidiaries.

Table 3:- Control measuring in the process production of raw milk, soft and pressed (hard and semi-hard) cheese.

\begin{tabular}{|c|c|}
\hline Steps & Control measuring \\
\hline $\begin{array}{l}\text { The raw material: } \\
\text {-Receipt of local raw milk }\end{array}$ & $\begin{array}{l}\text {-Check and control the health program and maintenance of premises and } \\
\text { separation zones, personal hygiene "Uniforms of clothing + body and hand } \\
\text { hygiene" } \\
\text {-Managing the storage conditions of raw material, raw milk must be } \\
\text { refrigerated no later than } 2 \text { hours after milking at } 4^{\circ} \text { Cmaximum. } \\
\text {-Systematically Control of microbiological parameters especially } \\
\text { physicochemical at the arrival of milk. } \\
\text {-Strict compliance with hygiene "rule of } 5 \mathrm{M}, \text { " sampling conditions of raw } \\
\text { milk "healthy collection». } \\
\text {-Respect the standards determining the initial quality of the raw material } \\
\text {-Cleaning and disinfection of equipment } \\
\text {-Avoid collecting milk from animals treated with antibiotics and mastitis } \\
\text { milk. }\end{array}$ \\
\hline Pasteurization/ sterilization & -Check scales pasteurization (time/temperature) \\
\hline
\end{tabular}




\begin{tabular}{|c|c|c|}
\hline \multirow{2}{*}{\multicolumn{2}{|c|}{ Cleaning and disinfection }} & -Regular maintenance pasteurizer \\
\hline & & $\begin{array}{l}\text {-Checked the status and validity, and the dose of disinfectant used. } \\
\text {-Checked the correct operation of CIP }\end{array}$ \\
\hline \multirow{3}{*}{$\begin{array}{c}\text { Cheese } \\
\text { production } \\
\text { (Soft and } \\
\text { pressed } \\
\text { cheese) }\end{array}$} & $\begin{array}{l}\text { Maturation } \\
\text { "direct } \\
\text { Inoculation" }\end{array}$ & $\begin{array}{l}\text {-Strict hygiene rules of premises and personal. } \\
\text {-Respect the time of lactic acidification, it should be sufficient. } \\
\text {-Cleaning and disinfection of equipment } \\
\text {-Use of selected cultures, in sufficient number for the conditions of } \\
\text { manufacture } \\
\text {-Good quality of enzyme preparations used for adequate temperatures. } \\
\text {-Walk forward. }\end{array}$ \\
\hline & $\begin{array}{l}\text { Salting } \\
\text { "Brining" }\end{array}$ & $\begin{array}{l}\text {-Good preparation of concentrated } \mathrm{NaCl} \text { solution used and respect the } \\
\text { salting time "Brining" }\end{array}$ \\
\hline & $\begin{array}{l}\text { maturing / } \\
\text { conditioning }\end{array}$ & $\begin{array}{l}\text {-Respects the parameters of ripening 'time and temperature' } \\
\text {-Sterile packaging; hermetic } \\
\text {-Check the temperature and humidity of the workshops. }\end{array}$ \\
\hline \multicolumn{2}{|c|}{ Storage/ marketing } & $\begin{array}{l}\text {-Cold preservation during the storage, transport and distribution (Humidity } \\
\text { and temperature). } \\
\text {-Respect the deadline consumer of the product } \\
\text {-Loading and unloading extended of dairy products should be avoided. } \\
\text {-Separation of dairy products in the storage location. }\end{array}$ \\
\hline
\end{tabular}

\section{Discussions:-}

\section{Physicochemical analysis:-}

The $\mathrm{pH}$ values obtained were situated in the range of values given by several authors working on these products. Indeed, $84 \%$ of the results for Klila samples were consistent with the results of (Mennane, 2008; Rhiat et al., 2013) which had values vary from 3,8 to 4,7 and 3,89 to 4,26 respectively. However, the results of $\mathrm{pH}$ and titratable acidity for Jben samples low compared to those cited by (Rhiat et al., 2011).

The results of titratable acidity indicate that $52 \%$ of Klila samples were in the range of mean values given by (Hamama, 1989b; Kbibou, 1987), which the values obtained were 9,9 and 11,16g/l respectively.

The samples analyzed of Jben were characterized by relatively low titratable acidity and a slightly acidic $\mathrm{pH}$ reflecting the absence of an active lactic fermentation, may be due to the inhibitory activity of plant extracts used for the coagulation of milk (Lahsaoui, 2009).

The total solids is generally more important in the Klila product given its dry nature, while for Jben sample results were close to those found by (Hamama and Bayi, 1991) which were located in the range of 29,4 and $45,6 \%$.

This difference is a consequence of salting fresh cheese and drainage time. This richness of dry matter of Jben product gives it a relatively firm consistence. According to (Hamama and Bayi, 1991), two major constituents of the dry matter are the fats and proteins which have an average of 16,5 and $15,8 \%$ respectively.

\section{Bacteriological analysis:-}

It should be noted that only fresh cheese "Jben" which is cited in the Algerian regulation, and there is no bacteriological standard for Klila product. Therefore, we have adopted the bacteriological parameters limits given by the Moroccan legislation (NM 624-04, 2004) to judge its hygienic quality.

The average values of aerobic bacteria of Klila and Jben samples were close to those given by (Rhiat et al., 2013; Mennane et al., 2007) which are $1,2 \times 10^{6}$ and $2,2 \times 10^{5} \mathrm{cfu} / \mathrm{g} ; 4,4 \times 10^{5}$ and $2,8 \times 10^{6} \mathrm{cfu} / \mathrm{g}$ for Klila and Jben samples respectively, and remain lower than those found by other studies in Morocco namely (Hamama, 1989b ; Mahi et al., 1995; Hamama et al., 1995; Zahar et al., 1997) for fresh cheese "Jben".

The total coliforms results were correlated with the work of (Hamama, 1989a). In addition, we found that fresh cheese "Jben" samples are not contaminated with fecal coliforms. These results are in agreement with the work of (Mennane et al., 2007). 
However, fecal contamination is present in Klila samples with a large load close to the values given by (Hamama, 1989a; Rhiat et al., 2011) and that are $5,7 \times 10^{4}$ and $9 \times 10^{4} \mathrm{cfu} / \mathrm{g}$ respectively.

The significant number of fecal contamination can be the consequence of a rapid and massive propagation of the fecal flora initially present in the raw milk used for cheese preparation.

Additional contamination of cheese by this flora can occur during the various manufacturing stages, views often unsanitary conditions wherein the preparation of the cheese is conducted (Hamama et al., 1996).

Isolation results of Clostridium showed a contamination of 96 and $40 \%$ of Klila and Jben samples respectively. These results were higher compared to those found by (Mennane et al., 2007) which 35,7\% of Klila samples were contaminated by clostridia spores with absence of these contaminants in the fresh cheese "Jben". Most clostridia species are soil bacteria (Benyagoub et al., 2013), so their presence indicates a telluric contamination.

Staphylococci enumeration revealed the presence of coagulase-negative staphylococci (CNS) with a percentage equal to 26 and $80 \%$ for Klila and Jben product respectively. One sample analyzed of Jben "J5" was contaminated by $S$. aureus. These results are consistent with the work of (Hamama et al., 1996) which reported a 73\% contamination of fresh cheese samples examined by $S$. aureus with an average rate of $7 \times 10^{4} \mathrm{cfu} / \mathrm{g}$, although only one sample has a population of pathogenic $S$. aureus greater than one million germs per gram.

The absence of pathogenic microorganisms namely Salmonella $s p$ and Shigella $s p$, and that in all the analyzed samples is explained by the absence of contamination in milk and milk products at the source (Secke, 2007);

- Original: milk from sick or carrier animals;

- Direct: carriers or sick individuals;

- Indirect: contacting the dairy product with a polluted environment during the preparation.

\section{Hazards analysis:-}

The prerequisite programs (PRP) represent the conditions and basic activities needed to maintain a hygienic environment for the production, storage and the provision of safe finished products throughout the process (Wallace and Williams, 2001). The prerequisites section, we have focused our efforts on education and personnel training on hygiene behavior, organized movement of raw materials, waste and personnel to avoid cross contamination.

However, the hazard analysis has been established only after the manufacturing diagram has been verified. It was carried out step by step the receipt of raw materials to the shipment of the finished product: First, we began by identifying hazards that are classified into three general types: biological (contaminants and pathogenic microorganisms), chemical (toxic substances) and physical (foreign bodies).

A 'HACCP' plan bringing together the key information of hazard identification revealed the existence of six critical points at different production stages of raw milk and the production process of dairy products, in which hazards are either biological 'microbial origin', which its parameters are determined in the regulations, or else physical and/or chemical. They are at: receipt and storage of raw materials 'raw milk'; Pasteurization/Sterilization; Inoculation and maturation; packaging; refrigeration and storage of finished product; cleaning and disinfecting, Benyagoub and Ayat (2013), it is imperative to be controlled by preventive and corrective measures that the industry must undertake to prevent the frequency of appearance of microbiological hazards probably the origin of food borne disease among consumers.

Awareness actions and information on potential risks are essential for consumers.

\section{Conclusion:-}

The results could highlight physicochemical and bacteriological properties of traditional cheeses namely Klila and Jben marketed at different towns in the southwest of Algeria compared to those reported in the regulations.

However the absence of pathogenic organisms in substantially all of the samples analyzed, we recorded a high rate of fecal contaminants (total and fecal coliforms), which represent not only a factor in the deterioration of the quality of products but also may pose a risk to the health of consumers especially the presence of $S$. aureus recognized as the causative agent of food-borne infection 
It is clear from this study, the importance of adopting a suitable manufacturing process that is vigilant and simple to prepare fresh cheese, fresh or dry white cheese, while respecting the measures of good hygienic practices and good manufacturing practices (GMP and GHP) to reduce the contamination level that can be produced and thus have a safe product and in compliance with the physicochemical and bacteriological standards established.

\section{References:-}

1. AFNOR. 1980. Milk and milk products, analysis methods. French standards association.

2. Alomari, A. Quasem, JA. and Mazahreh, AS. 2008. Microbiological analysis of solar and freeze-dried jameed produced from cow and sheep milk with the addition of carrageenan mix to the jameed paste. Pakistan Journal of Nutrition.7(6):726-729.

3. Benyagoub, E. Ayat, M, Dahan, T. and Smahi, K. 2013. Level of control of the hygienic quality of camel milk (Camelus dromedarius) in south west Algeria and its impact on security. Peak Journal of Food and Science Technology. 1(4):53-60.

4. Benyagoub, E. and Ayat, M. 2013. Microbiological level control of contaminating microorganisms in the production of milk at a state dairy industry Southwest Algerian. Phytochemistry \& Bioactives Substances Journal.7(2):57-73.

5. Blanc D. 2007. ISO 22000, HACCP and food safety. Recommendation tools, FAQ and returns of field. AFNOR

6. Codex Alimentarius. 2003. Hazard Analysis System, Critical Control Points (HACCP) and guidelines for its application', Appendix to CAC/RCP 1-1969 Rév 4: 5-24.

7. Dharam, P. and Narender, RP. 2007. Indian traditional dairy products: an overview. International Conference on Traditional Dairy Foods. November 14-17. Ndri, Karnal (India)

8. El Marrachi, A. and Hmmama, A. 1996. Aspects hygiéniques du fromage frais de chèvre: Perspectives d'amélioration de la qualité. Les perspectives de développement de la filière lait de chèvre dans le bassin méditerranéen. Une réflexion collective appliquée au cas marocain. Titre de série: Etude FAO: Production et santé animales, 131.

9. Faye, B. and Loiseau, G. 2002. Sources of contamination in the dairy sector and examples of quality approaches', CIRAD, FAO, Montpellier

10. Galina, MA. Claps, S. Rubino, R. Pizzillo, M. Guerrero, M. and Pineda, LJ. 2011. Cheese chemical profile from Zebu cows grazing on two systems - pastoral and silvopastoral - in the highlands of Colima, Mexico', Dairy Production in Mountain: farming systems, milk and cheese quality and implications for the future: 10th International Meeting on Mountain cheese, 14-15 September, Dronero, Italy: 17-18

11. Hamama, A. 1989a. Qualité bactériologique des fromages frais marocains. Options Méditerranéennes : Série A. Séminaires Méditerranéens. $6: 223-227$.

12. Hamama, A, Zahar, M, El Marrakchi, A, Aboulala, F. and Bent Mohamed Aberrahman, M. 1995. Préparation du framage frais à partir du lait recombiné. Actes Institut Agronomique et Vétérinaire Maroc.15:21-26.

13. Hamama, A.Lotfi, N. and El Idrissi, AH. 1996. Hygiène du lait à la production'Rabat: Proceedings de la Journée sur la qualité du lait organisée par la Direction de l'Elevage, l'Institut Agronomique et Vétérinaire Hassan II et l'Association Nationale des Eleveurs de Bovins, 20 juin 1996.

14. Hamama, A. 1989b. Studies of the hygienic quality of Moroccan traditional dairy products. Ph.D Thesis : University of Minnesota, USA, pp: 1-35.

15. Hamama. A.and Bayi, M. 1991. Composition and microbiological profile of two Moroccan traditional dairy products: Raïb and Jben. Journal of the Society of DairyTechnology.44(4):118-120

16. ISO 4832. 1978. Microbiologie-Directives générales pour dénombrement des coliformes-Méthodes par comptage de colonies obtenues à $30^{\circ} \mathrm{C}$. Organisation Internationale de Normalisation.

17. ISO 707. 1994. Milk and dairy product-sampling method. International Organization for Standardization

18. ISO 11869. 1997. Yoghurt-Determination of titratable acidity-potentiometric method. International Organization for Standardization

19. ISO 8261. 2001. Milk and milk products-General guidelines for the preparation of test samples, initial suspension and decimal dilutions for microbiological examination. International Organization for Standardization.

20. ISO 5944. 2001. Milk and milk products-detection of coagulase positive Staphylococci, Technique of the most probable number. International Organization for Standardization.

21. ISO 6785. 2001. Milk and milk products-Detection of Salmonella spp. International Organization for Standardization. 
22. ISO 13580. 2005. Yoghurt- Determination of total solids content. International Organization for Standardization.

23. Kbibou. G. 1987. Étude bactériologique des produits laitiers traditionnels. Thèse de Doctorat: Science vétérinaire, Institut Agronomique et Vétérinaire Hassan II, Rabat, Maroc.

24. Lahsaoui, S. 2009. Étude du procédé de fabrication d'un produit laitier traditionnel Algérien (Kilila)', Thèse de Doctorat : Science Agronomie, université de Batna (Algérie), $72 \mathrm{p}$

25. Leyral, G. and Vierling, E. 2007. Microbiology and toxicology of food: food hygiene and safety'. Doin CRDP d'Aquitaine, Biosciences et techniques : Sciences des aliments, Bordeaux

26. Mahi, N. Hamama, A, and Aboudrar, W. 1995. Préparation du jben pasteurisé à l'aide de levains lactiques sélectionnés. Actes Institut Agronomique et Vétérinaire Maroc.15:27-32.

27. Mazahreh, AS. AL-shawabkeh, F. and Quasem, JM. 2008. Evaluation of the chemical and sensory attributes of solar and freeze-dried jameed produced from cow and sheep milk with the addition of carrageenan mix to the Jameed paste. American Journal of Agricultural and Biological Sciences.3(3):627-632.

28. Mennane, Z, Khedid, KB. Zinedine, EA. Lagzouli, M. Ouhssine, M. and Elyachioui, M. 2007.Microbial characteristics of Klila and Jben traditional Moroccan cheese from raw cow's milk. World Journal of Dairy and Food Sciences. 2(1):23-27.

29. Mennane, Z. 2008. Lait et produits laitiers entre la tradition et la biotechnologie. Étude physico-chimique et microbiologique. Thèse de Doctorat : Microbiologie, Université Ibn Tofaïl, kénitra (Maroc), 175p.

30. NA 678. 1994. Lait-Détermination de l'acidité titrable. Norme Algérienne.

31. NA 679. 1994. Lait -Détermination de la teneur en matière sèche.NormeAlgérienne.

32. NA 35. 1998. Decree of 27 May 1998, Standard on microbiological criteria for milk and dairy products; Technical to sample and interpretation of the results of microbiological analyzes. Algerian standard.

33. NF V04-207. 1994. Milk - Determination of dry matter content. French Standard

34. NF V04-206. 1994. Milk-Determination of titratable acidity. French Standard

35. NF V04-016. 1985. Milk-Enumeration of microorganisms, colony count technique at $30^{\circ} \mathrm{C}$.standard French.

36. NF T 90-415. 1985. Testing water - Detection and enumeration of the spores of sulfite-reducing anaerobes and sulfite-reducing clostridia - General method for incorporation in agar deep tube. French standard.

37. NM 624-04. 2004. Arrété relative aux normes microbiologiques auxquelles doivent répondre les denrées animales ou d'origine animales. Norme Marocaine.

38. Notermans, S. Zwietering, MH. and Mead, GC. 1994. The HACCP concept: identification of potentially hazardous microorganisms.Food Microbiology. 11:203-214.

39. Rhiat, M. Labioui, H. Driouich, A. Aouane, M. Chbab, Y. Driouich, A. Mennane, Z. and Ouhssine, M. 2011. Étude bactériologique comparative des fromages frais marocains commercialisés (Mahlabats) et des fromages fabriqués au laboratoire.Afrique Science. 7(3):108-112.

40. Rhiat, M. Labioui, H. Driouich, A. Mennane, Z. and Ouhssine, M. 2013. Preparation of the starter Trial production of cheese Jben and Klila at laboratory scale. Food Science and Quality Management. 13:1-8.

41. Secke, C. 2007. Contribution à l'étude de la qualité bactériologique des aliments vendus sur la voie publique de Dakar', Thèse de Doctorat : Science vétérinaire, Université de Dakar, 90.

42. Shaker,RR. Jumah, RY.Tashtoush, B.and Zraiy, AF. 1999. Manufacture of Jameed sing a spray drying process, a preliminary study. International Journal of Dairy Technology.52(3):77-80.

43. Wallace, C. and Williams, T. 2001. Pre-requisites: a help or a hindrance to HACCP. Food Control. 12:235-240.

44. Zahar, M. Smith, DE. and Hamama, A. 1997. Manufacture of Jben, Moroccan traditional fresh cheese, from recombined milk'.Milchwissenschaft.52(11):618- 622. 